This is an Accepted Manuscript of an article published by Taylor \& Francis in Mind, Culture, and Activity on 30/10/19, available online:

https://www.tandfonline.com/doi/abs/10.1080/10749039.2019.1683208?journalCode=h $\underline{\operatorname{mca} 20}$ 


\title{
The Internet as a Global Playground: Young Citizens and Informal Spaces of Agency, a Portuguese Case Study
}

\author{
The recent rapid expansion of digital technologies brought with it the promise \\ that these technologies would bring citizens, and especially youth, closer to \\ political decision-making processes. But studies on youth participation and \\ technology suggest that this promise has failed to materialize. The present article \\ looks at nontraditional and informal online forms of civic participation to better \\ understand students' civic agency when using the Internet. Results from a \\ countrywide survey of 11th- and 12th-grade students in Portugal suggest that \\ their informal online civic participation (e.g., posting and sharing civically \\ relevant items) is positively correlated with their formal civic participation offline \\ (e.g., in community groups and school decision-making), perceived opportunities \\ to participate offline, and formal online civic participation. In addition, students \\ tend to react to and share civic content on online social networks more often than \\ they perform more structured and formalized civic actions. The results suggest \\ that the Internet is a space of youth civic agency and participation - a global \\ playground - contrasting with formal institutional and formal online spaces, \\ where youth lack a voice.
}

Keywords: civic participation, transformative agency, civic agency, Internet, youth civic participation, global playground

\section{Introduction}

The emergence of interactive digital technologies came with the promise that they would bring citizens closer to political decision-making processes, reaching more people, enabling them to participate, and providing more accessible and diverse information (Macintosh, 2004; OECD, 2003). In turn, this was expected to allow people to make more enlightened and fruitful contributions to public debate (Hirst, 2013; Macintosh \& Whyte, 2006), reduce dissatisfaction, and restore confidence in democracy (Klingemann, 2013; Pharr \& Putnam, 2000; Torcal, 2006). 
However, studies have shown that young citizens tend not to use technologies for formal civic or political participation (Hasebrink, Livingstone, Haddon, \& Ólafsson, 2009) such as signing an online petitions, taking part of formal online consultation process or participating in an online formal governmental public decision-making process.

It has also been found that, when online, young people are becoming more disconnected from traditional forms of civic participation (Banaji \& Buckingham, 2010, 2013; Kahne, Middaugh, \& Allen, 2015) and thus commonly do not take advantage of the Internet's affordances for these purposes. Other authors consider that civic participation studies tend to address traditional (offline) modes of activism or formal modes of public participation (either offline or online: e.g., signing a petition, taking part in a formal consultation process or formal governmental public decision-making process), and are less focused on minors and new forms of civic activity (MiloševićĐorđević \& Žeželj, 2017). The latter may include actions such as liking, sharing or commenting on images, videos, GIFs or any other media object, which involve interactive technologies and are less hierarchically structured than formal participation channels Thus, young people's actions are often seen as fruitless or associated to online pseudo-activism or “clicktivism” (Sormanen \& Dutton, 2015; Tarrow, 2014).

Finally, studies on the Internet and youth highlight both evidence that young people's offline civic actions are not being included in decision-making processes (Caron, 2018; Coleman, 2006) and the tendency of those who are already civically engaged offline to participate in civic life through online channels (Norris, 2011; Prout, 2000). In addition, a number of studies have emphasized the importance of online social networks, giving evidence that they play a major role in civic political engagement and 
participation (Feezell, Conroy, \& Guerrero, 2009) and in social movements and collective action (Bennett, 2008; Bennett \& Segerberg, 2012).

The data presented here are drawn from a multiple case study in Portuguese secondary schools and municipalities that addresses the interrelations between municipal and school policies and strategies, secondary students' Internet usage, and students' civic participation both offline and online. The guiding research question was "How can education for media literacy be conducive to participatory e-citizenship among young people?" The study, which drew on questionnaires about online behavior and civic participation filled out by nearly 1,400 secondary students around the country, had three aims. The first was to analyze how municipal and school decision makers, policies, and strategies provide, or fail to provide, for young people's offline and online participation. The second was to explore the impacts of these municipal and school measures on secondary students' levels of offline and online participation. The third was to understand students' online civic participation actions, as well as how they perceive themselves as citizens. The present paper focuses more specifically on the latter aim, analyzing the data also through the lens of agency.

These data on nontraditional (new) forms of online civic participation may contribute to filling gaps in our understanding of young people's civic agency and participation off- and online, and their reasons for participating (or not). Although they report on the Portuguese context, the findings may help educators to adjust their teaching strategies with regard to promoting civic agency and participation both online and in general, and thus to enhance the development of civic agency in countries with similar educational systems.

\section{Agency and Civic Participation}

According to Giddens (1984), agency can best be understood as the capability to do 
things, rather than the actual intention to do them. Other authors understand agency reflexively, as individuals' ability to act upon and transform the world in which they act. Inden (2000), for example, describes it as

the realized capacity of people to act effectively upon their world and not only to know about or give personal or intersubjective significance to it. That capacity is the power of people to act purposively and reflectively, in more or less complex interrelationships with one another, to reiterate and remake the world in which they live. (p. 23)

Hays (1994) also argues that "Agency explains the creation, recreation, and transformation of social structures; ... and the capacity of agents to affect social structures varies with the accessibility, power, and durability of the structure in question" (p. 62).

The conception of agency as the ability to transform social and personal conditions resulting from a reflective, interpersonally interactive process is related to Dahlgren's (2012) concept of civic agency when using technologies. Dahlgren points to a subjective aspect of civic agency, wherein "citizens feel that they in concert with others, can in some way make a difference, that they can have some kind of impact on political life, even if they do not win every battle" (2012, p. 40). Forestiere (2015) advances a notion of civic agency not only as a capability but as an approach requiring an "ethos that maintains that individuals living in vibrant democracies need to listen, to learn, to interact, to deliberate, and to problem solve" (p. 456) — thus, an active commitment to participate in civic processes. Furthermore, Clot (2009) points out that our individual activity and our "power to act" can be fostered or constrained by the collective's activity, agency being the ability to work through these tensions. 
Just in these few examples, we thus have agency variously identified as (1) the capability to act, (2) effective action, (3) reflexively transformative of the agent's world, (4) a sense (or feeling) of having the capability to act, and (5) an ethos of participatory/transformative action. These can all be applied in the context of young people's activities online and civic life: agency can be understood as having the ability to take effective civic action online, the sense of being able to take such potentially transformative action, the fact of actually taking such action (which I will call participation), and the commitment to doing so.

Online platforms and objects have taken on an important role in the sphere of civic action, affording new forms of collective political activity (Ahuja, Patel, \& Suh, 2018). Investigating young people's public voice online - their production, reproduction, and interaction with online objects (Caron, 2018) - is thus crucial to understanding the dynamics of youth civic agency and participation overall. As Dahlgren (2012) notes, participation "is central to our understanding of both media audiences and the practices of civic agency today" (p. 28).

The present article focuses on the data from the student questionnaire that address the aspects of agency referred to above, both offline and online, particularly (1) the capability to participate, (2) the subjective sense (or feeling) of having the capability to participate, and (3) effective participation. By understanding these three aspects of agency, we will be better able to prepare students to deal with online platforms and objects and thus foster transformative agency. Furthermore, I will argue that the Internet represents a way for young people to experience transformative agency differently than through more traditional means of civic participation. 
No consensus on the definition of civic participation emerges from the literature. ${ }^{1}$ Civic participation (or engagement) has been defined as formal group membership and social and democratic participation (Putnam, 1995; Shah, 1998), which notably includes traditional activities such as being a member of a club, protesting, voting in elections, attending town hall meetings, and union membership. Caron (2018) observes that young people are excluded from formal politics and decision-making processes (e.g., due to voting age restrictions) and highlights the importance of understanding their online participation. Their status as citizens is thus kept on hold in the social structure of Western societies. This exclusion means that young people generally have, at best, limited preparation to participate in formal civic processes at some later stage.

Nonetheless, the Internet offers spaces and forms of civic action that are not subject to the same age restrictions. The study of civic participation must therefore be expanded to these spheres where adolescents do find opportunities to participate. This involves looking at data on how adolescents use informal spaces to express their thoughts and to participate civically in less traditional ways.

Jackson, Alexander, Thorsen, and Savigny (2015) also argue for the importance of exploring how technology does or does not facilitate civic agency by understanding the challenges, opportunities, and "barriers to empowerment experienced by marginalized people; and the ongoing tension between the mainstream (be it mainstream media, culture or political institutions) and the margins" (p.11), which, in this case, are young people.

\footnotetext{
${ }^{1}$ It is common to see the terms engagement and participation used interchangeably (Vissers \&
} Stolle, 2014). This paper will treat the two as equivalent. 


\section{The Global Playground as an Informal Place of Civic Participation}

The Internet makes political and social questions readily accessible through informal affordances. For youth in some societies, who make massive use of digital technologies through mobile devices in daily life, including in school, the Internet represents a space of agency. I call this a global playground: a space where they have a sense of making their own rules, contributing to the development of a community, and even in some cases creating new personas. The ability to collect, share, and engage with political posts, images, and entertainment resources may provide a sense of freedom and belonging that differs from the forms of experience (and indeed, of exclusion) associated with formal channels of civic participation (e.g., signing a petition, starting a political or social campaign, taking part in a formal consultation process or formal governmental public decision-making process).

The United Nations Convention on the Rights of the Child attributes special rights of protection to children. There is a tension between these aims of protection and the aim of promoting the development of children's autonomy as fully fledged citizens (Jans, 2004; Prout, 2000): some societies aiming to protect children surround them with care by increasing levels of control, regulation and surveillance, but this can prevent them from developing the means for self-realization and autonomy. The latter require children to make decisions about their daily life (e.g., what and when to play, eat, wear, read, study) and/or express their ideas freely in dialogue about such decisions, enabling them to develop the ability to determine themselves through practice, and thus their identities and capabilities as agents. Thus, when adult decisions based on the aim of protection tightly restrict the available range of options and experiences, this may prevent young people from developing a sense of responsibility and empowerment 
(Jans, 2004; Kirby, Lanyon, Cronin, \& Sinclair, 2003) and influence their selfperception as citizens (or citizens-to-be).

In addition, seeing young people only as future citizens may contribute to reducing the chances that they will participate in democratic institutions later in life (Bragg, 2007; Head, 2011). For people to see themselves as citizens, they must be involved in democratic processes (Dahlgren, 2006). Consequently, being kept on hold as citizens prevents youth from experiencing a socialization process that allows them to develop a sense of themselves as civic agents, capability for civic action, and a commitment to participating in democratic life.

Following a growing recognition of the importance of involving youth at the municipal level, in 2009 the Portuguese government instituted municipal youth councils as advisory bodies to municipal governments throughout the country (Assembleia da República, 2009). Their official aims were to involve young people in consultation processes, informing them about policies while keeping control of the decisions in the hands of policy makers. These may be seen as artificial exercises which fail to increase young people's levels of involvement in democracy (Coleman, 2006; Hart, 1992; Kirby et al., 2003; Shier, 2001). In this context, the Internet, as a global playground, may represent a space for informal civic participation, offering opportunities for civic action and allowing informal learning about social values — a space for agency.

The concept of the global playground was developed within the wider study from which this paper is drawn. It is based on the metaphor of the school playground, where youth (a) find their own spaces away from adults to do their own things and build social relationships; (b) mimic what others do; (c) test boundaries established by adults; (d) act as multipliers and civic educators of their peers; and (e) take actions that are individual choices and not formal obligations. 
The set of features available through virtual environments (i.e., multimodal information sources that are interactive and less hierarchically structured than formal participation channels) may make them more suited than traditional media such as newspapers and television to invite and motivate young people to search for information and cope with different modes of information (e.g., games, chats, discussions, and still or moving images), political ideas, or ethical values.

Moreover, among the things that the Internet provides young people with the power to act may be influencing others in their environment (Puljek-Shank, 2018).

The ability to do things such as collect and share information, including political posts, images, and entertainment resources, may offer them a sense of freedom, without necessarily being associated with a corresponding feeling of responsibility for their actions. They may not be aiming at participating in public life, but by sharing, posting and liking in this shared global playground, they end up acting as multipliers of content, values, and ideals - engaging in what Dahlgren (2012) calls "civic practices"influencing others and being influenced in turn.

Intentionally or not, with varying degrees of awareness concerning the implications of their actions (and thus of self-understanding as potentially transformative agents), young people choose to reproduce videos, images, and other media content online that are related to political life in some way. Sharing satirical cartoons, videos about plastic and its impacts, or a YouTube video on school cyberbullying and helping it go viral may all be considered new forms of civic agency. As Sannino (2008) suggests, "the transformative potential of an activity lies in its object being the motive of the activity itself' (p. 242). Thus, students' activities with online media objects involving civic content and affordances can lead to changes in the 
structure of the students' own relationship to the world as a space of (potentially, civic) action.

The notion of the global playground is also in the spirit of Jenkins, Clinton, Purushotma, Robinson, and Weigel's (2006) concept of participatory culture. This term refers to a culture where individuals face low barriers to artistic expression and civic participation, where they can create and share their productions, and where they believe that their contributions matter.

Those with access to the Internet and the ability to interact with web objects can do things more easily, quickly, and cheaply, which provides them with a sense of agency (Boerl, 2013; Jenkins, 2006; Jenkins, Shresthova, Gamber-Thompson, KliglerVilenchik, \& Zimmerman, 2016; Sasaki, 2016). Thus, in order to prevent young people from feeling powerless, it is important to provide them with the social and cultural capital (Bourdieu, 1986) they need to navigate the Internet (Pearce \& Rice, 2017; Possey et al., 2018; Wells, 2015). Finally, following Sannino's (2008) argument, it is important to foster a reflective process on how they interact with and their attitudes towards objects, in this case, online.

\section{The Internet as a Learning Space}

In this context, schools may have a determining role to play in promoting the development of the cultural capital, skills, and access involved in civic agency, particularly online.

By allowing individuals to choose what to engage with and what to share, while algorithms filter the content shown to individuals based on their previous online activities, the Internet fosters a proliferation of values, lifestyles, and political ideologies, with both positive and negative impacts on social and democratic life. Importantly, just as bullying, discrimination, and violence occur in school playgrounds, 
undesirable actions also happen in the global playground. Thus, as Banaji and Buckingham (2013) point out, "a recurring assumption that [online] participation will somehow necessarily operate in the interests of democracy ... is far from warranted" (p. 162).

Schools and education thus need to be prepared to deal with the fundamental challenge facing today's young people in their globalized world: making sense of the synchronicity and copresence of others, the blurring of who is who and what is private or public. The global playground is a social space that is vulnerable to hegemony, governed by market and political forces that are still little known to the general public (Zuboff, 2019). Educational actors thus need to prepare students to deal with censorship and surveillance by the state, employers, or other established elites (Cammaerts, 2008), as well as algorithms which function as opinion reinforcers (Davies \& Merchant, 2009; Greenfield, 2017).

If we intend to use these new tools to foster young people's civic participation, and thus their transformative and civic agency, we need to consider that their learning process cannot take place only through their online interaction. Consequently, schools and political decision makers must take on the responsibility of providing them with opportunities to develop digital and media skills, reducing their vulnerability to the risks of a virtual environment. As pointed out by Livingstone and Third (2017), virtual environments raise concerns about children's rights, as these spaces can pose threats to their safety. As in the case of the school playground, possible negative dynamics must be identified and monitored, but far more importantly, young people must be empowered with the knowledge, skills, and dispositions they need to deal with these threats, without allowing protective measures to undermine their developing autonomy or to reduce their social and political participation. 
To do this, it is important to understand their online actions, without undermining their ability to create, share, react to, and actively participate and engage with different forms of media related to social, political, and environmental issues. It is in this spirit that this paper presents data on the participation of secondary school students, both offline and online, through the different facets of agency.

\section{Methodology}

This paper reports on a set of 12 case studies on municipalities and secondary public schools in Portugal. A mixed methods approach was used because of the need to triangulate between a range of different data types and sources (interviews and questionnaires; municipalities and schools; mayors, teachers, and students). It also provided means to combine qualitative and quantitative elements during data collection and analysis (Johnson, Onwuegbuzie, \& Turner, 2007; Lucero et al., 2018). Data were collected from students, teachers, and municipal officials on a range of issues related to young people's media literacy and citizenship, but the present paper will only focus on data concerning students' offline and online civic actions, as collected from students using a paper questionnaire.

The schools were chosen by applying a cluster sampling process (using the Latent GOLD 4.5) on Portuguese municipalities, using a set of educational and Information and Communication Technologies (ICT) indicators. Within the resulting five clusters (three in mainland Portugal and two in the Azores region), the schools were chosen randomly, with the exception of two schools that were chosen for reasons of convenience. These indicators included the number of students in Grades 10-12, the number of computers per school, and the transition rate/completion of regular secondary education in each municipality (see Dias Fonseca \& Potter, 2016; for complete details, see Dias Fonseca, 2015). Ethical approval to collect the data from schools was granted 
by the universities involved and the Ministry of Education. The data presented here are drawn from questionnaires designed by the author as part of her doctoral study. After an initial pilot with students in the same age range, the questionnaires were filled out by 1,392 students in Grades 11 and 12, aged 15-21 years $(M=16.69 ; S D=1.005)$, after the students - and their legal guardians - gave their informed consent.

\section{Data Analysis}

The student paper questionnaires were administered in each school by the author in 2013-2014. For this article, a data set with students' questionnaires was developed, including open and closed questions concerning their offline and online civic participation (Table 1), their reasons for participating (or not participating), and their Internet access. The descriptive statistics on the closed questions concerning students' Internet use and access offer information on the basic capability aspect of agency: that is, the power to act, independent of whether or not they have reasons for doing so (Giddens, 1984, Jenkins et al., 2016). Questions on their informal and formal online participation allow the analysis of their effective action as civic agents (Dahlgren, 2012; Forestiere, 2015). And questions on their perceived opportunities to participate reflect their sense of being able to participate (Dahlgren, 2012).

[Table 1 here]

Table 1. Example Questionnaire Items Analyzed

A content analysis was conducted for the open questions, followed by a descriptive statistical analysis. The content analysis was performed on responses to open questions asking for the reasons why students (a) do not participate offline; (b) do not vote for their social bodies and government bodies; and (c) think they cannot participate, or that they can participate but are not interested, in social bodies, school 
decisions, and social issues. The content analysis was conducted in five stages: (1) reading the open questions and identifying patterns; (2) categorizing the patterns and creating the codes; (3) analyzing the responses using the codes; (4) conducting quality control, with other researchers contributing to the discussion and validation of the codes; and (5) performing final analysis using the validated codes.

Through this process, students' reasons for not participating or declining to participate formally offline were identified and described, and a descriptive statistical analysis was performed on the validated codes. This coding addresses the reasons for the inaccessibility of formal and traditional forms of civic participation to young people The codes that emerged for the "I can't participate" responses were the following: "It is the responsibility of adults/politicians;" "Must be over 18;" "Not interested in politics;" "Feeling of powerlessness;" "Nothing to change;" and "No time due to school demands." The codes that emerged for the "I can, but I'm not interested" responses were "Lack of empowerment;" "It is the responsibility of adults/leaders;" "Must be over 18;" "Disbelief in politicians/ political system;" and "Nothing to change."

The quantitative data from the questionnaires were used to produce four composite scores reflecting students' offline and online civic participation and their perception of their opportunities to participate. The reason for developing the composite scores was to allow a deeper understanding of students' online civic participation, an aspect of civic agency, as described above. At the same time, it differentiates levels of skills and dispositions, for example, commenting on a post involves a different set of skills and dispositions than liking a post. Examples might include videos about plastic and its impacts, images of migrant children and adults, or satirical cartoons. Sharing a YouTube video on cyberbullying and helping it go viral, tweeting a statement of rage 
against the school testing system, or even debating by manipulating a photographic image may all be considered new forms of activism and civic participation.

To produce the composite scores, the questionnaire items were scored and summed as shown in the following table (adapted from Dias-Fonseca \& Potter, 2016).

[Table 2 here]

Table 2. Composite Score Characterizations

After this process, Pearson product-moment correlation coefficients $(r)$ were computed using SPSS (v. 22) to investigate the strength and direction of relationships between the composite scores (excluding the two schools not chosen through the random selection process). Preliminary analyses were performed to ensure that the assumptions of normality, linearity, and homoscedasticity were not violated. A significance level of $\alpha=.05$ was used.

\section{Findings and Discussion}

The data presented in this paper relate to students' civic agency offline and online, as well as to correlations between the two. This section is divided into four subsections. The first concerns students' participatory action offline, in the community. The second focuses on students' perceived power to participate. The third looks at students' online actions, understood as formal and informal civic participation, with an emphasis on identifying new forms of informal civic participation, which reflect their transformative and civic agency. The final section addresses the correlations between participation in the offline and online contexts. Each section looks at the different facets of agency identified in the introduction: capability to act, effective participation, the sense of being able to participate, and the participatory ethos (i.e., commitment to participate). 


\section{Students' Offline Participatory Action-Effective Action and Agency Offline}

The data on offline civic participation are presented to test part of the first argument in this paper: namely, that young people experience a lack of voice and decision-making influence in institutions (e.g., Caron, 2018; Coleman, 2006) which contrast with what they can experience online.

Table 3 summarizes young people's responses when asked if they actively participate in activities or community groups, including formal organizations and youth local collectives (which are widespread in Portugal and commonly related to cultural activities such as music, folklore, or theatre, either traditional or contemporary). The majority do not take part in formal community groups in common areas of civic participation, meaning most students are not engaging in traditional means of civic participation (Putnam, 1995; Shah, 1998) and thus not manifesting civic agency in this active sense (Inden, 2000).

[Table 3 here]

Table 3. Students' Offline Civic Participation in Formal Community Groups: Descriptive Statistics $(N=1,332)$

\section{Students' Reasons-Sense of Capability to Act and Participatory Ethos of Agency}

The codes that emerged from the content analysis of students' responses to the open question "Provide a reason why you don't participate in the groups or associations presented" can be grouped into two main areas: reasons that might be described as external, and individual-level reasons. The external reasons include a lack of information in the city or village about these activities or groups $(4.6 \%)$, the non- 
existence of such groups where they live (18.5\%), lack of time due to school schedules (24.5\%), and a lack of encouragement to participate (4.6\%). The individual-level reasons were that they had no interest in doing so $(33.3 \%)$ or that they never thought that they could participate in such activities or groups (4.6\%). Although most of the codes show that young people tend to identify external reasons for their nonparticipation, the largest single group reports not being interested in participating. This lack of interest may also be a result of not experiencing a learning environment conducive to being civically active — something that can be eased by appropriate education, as argued by Coleman (2006) and Dahlgren (2012) — or of not having the experience of their actions affecting social structures, which, as Hays (1994 points out, depends on accessibility and power.

The questionnaire results on students' perceptions of their opportunities to take part in student representative bodies, school decision-making processes, and social and political issues, are presented in Table 4.

[Table 4 here]

Table 4. To What Extent Do You Think You Can Participate? Descriptive Statistics $(N=1,332)$

These findings are mainly focused on the students' sense of being able to act in these contexts (Dahlgren, 2012). Their answers to the question "To what extent do you think you can participate?" show that most students think they cannot be part of decision-making processes that are in fact available to them in Portuguese schools (e.g., designing school projects, student unions, etc.). The data also show that, in the same vein, students think they cannot participate in issues at the societal level, either nationally or internationally. Although they legally can, their socialization process is not 
explicit enough on this point to allow them to understand that they can; that is, they are not provided with an environment that involves them in well-established democratic practices (Caron, 2018; Coleman, 2006; Dahlgren, 2006; Hart, 1992; Kirby et al., 2003; Shier, 2001).

In addition, these findings may suggest a failure to cultivate and transmit a participatory ethos, an aspect of agency described by Forestiere (2015). This may ultimately affect the level of disaffection with democracy, as discussed by authors such as Magalhães (2005) and Torcal (2006).

Table 5 presents students' answers to the questions "Provide a reason why you think you can't participate" (asked when students reported that they thought they could not participate) and "Provide a reason why you can, but you are not interested in doing so" (asked when students reported that they thought they could participate but did not wish to). Many of those who felt they could not participate cited feelings of powerlessness, the idea that such participation is the responsibility of adults and/or politicians, and voting age-related reasons. This is consistent with the idea that young people feel that they lack voice and decision-making power in formal institutional contexts (Hart, 1992; Kirby et al., 2003; Shier, 2001). In Clot's (2009) terms, this may reflect a constraint on these young individuals' activity and sense of "power to act" due to adults' failure to involve young people in decision-making processes or to promote a participatory ethos. In particular, the reasons related to voting age and the idea that participation is the responsibility of adults or politicians support the idea that some young people see their citizenship status as being on hold. For example, one student wrote that "I don't have power for that, it's up to school management and the government," while another wrote that "I'm not old enough to act on these subjects." 
Table 5. Students' Main Reasons for not Participating or Declining to Participate Formally Offline: Descriptive Statistics ( $n=779$ and $n=775$, respectively)

Among students who report feeling able but uninterested in participating, responses such as disbelief in politicians/the political system and lack of empowerment suggest that although these young people perceive that they have the option of taking part in civic processes, they feel that this participation will not make a difference and thus that they do not have effective agency in that context (Dahlgren, 2012; Inden, 2000). For example, one student wrote that "I think it doesn't solve anything and I'm not going to waste my time," while another wrote, "I think that what I would do on these issues wouldn't influence anything, because I'm just a student," and a third wrote, "When it comes down to it, the opinion of the citizen doesn't make a difference." This may be interconnected with the level of distrust or dissatisfaction with democracy and participatory processes within the democratic system more generally, as discussed by Klingemann (2013) and Norris (2011).

\section{Online Informal and Formal Civic Participation-Capability, Sense of Capability, and Effective Action}

Moving on to online civic participation, it was first necessary to understand whether students had access to the Internet, and if so, how often they use it. These data provide us with insights on the existence of the basic infrastructural conditions for the students to have the power to act online (Giddens, 1984). These data are also important in light of results showing positive correlations between Internet access frequency and online civic participation (Banaji \& Buckingham, 2013; Kahne et al., 2015) and between access through private devices and online participation (Jenkins, 2006). The data in Table 6 show that the majority of the students are frequent users of the Internet, both on 
a smartphone and on a home computer.

[Table 6 here]

Table 6. Access to the Internet per Device: Descriptive Statistics $(N=1,332)$

The data in Tables 7 to 9 show how young people tend to use their voice on public questions in the global playground, by sharing and liking videos, images, and other media objects with some political dimension, rather than in formal online institutional contexts. The data on young people's online civic participation are organized into three main areas: (a) informal participation via online social networks, (b) informal participation in formal online spaces, and (c) formal participation in formal spaces. The data are derived from questions where students have to identify which actions they perform themselves and which actions they think only teachers would perform. The reason for this distinction is to shed light on which actions they consider to be dependent on age or status and which they see as part of their own sphere of action and/or capability. The results are presented in Tables 7 to 9 .

[Table 7 here]

Table 7. Informal Forms of Civic Participation via Online Social Networks: Descriptive Statistics $(N=1,332)$

The data clearly show that most of the young respondents were already engaging informally with civic content. The majority of these interactions relate to themes such as the environment, ethnic discrimination, and gender discrimination. The least-cited theme among all the forms of informal participation proposed in the questionnaire is "social, political or economic issues," although the other themes are, by nature, social and political. This may be understood in several ways: students may have interpreted 
this response as implicitly referring to other social, political, or economic issues, not listed; they may not have identified the other themes as social and political due to their levels of knowledge; or it may relate to the conventional vocabulary of formal civic participation—with terms such as "social", "political" and "economic" being less familiar to young people than "environment", "race" and "gender."

Furthermore, the high percentage of young people having liked and shared items related to issues such as gender discrimination demonstrates their power to act as agents, multipliers, and civic educators in the global playground - in the sense of Inden's (2000) description of agency as the realized capability to act effectively. When considered together with young people's observed lack of participation in offline civic life, the findings also fit with Sannino's (2008) argument that the transformative potential of the agent's activity relies on the object the agent interacts with.

The percentage having commented in each category is significantly lower than the proportion having liked posts. Commenting involves higher levels of engagement and skills (e.g., writing, argumentation, and analysis) but it also involves a set of valuable dispositions (e.g., dealing in an orderly manner with the parts of a complex whole, confidence, courage). Clearly, students' decisions on what to share and react to are influenced both by algorithms and social constructions (Zuboff, 2019). Nonetheless, students are influenced by and, in turn, themselves influence the content that circulates within their online social networks, without necessarily understanding their actions in civic terms.

The findings thus suggest that it is important to promote critical thinking and digital skills among young citizens in order to foster constructive civic action online. This will also increase the chances that the students will be able to act meaningfully and 
purposively to remake the world they live in, in a transformative way (Inden, 2000) and, as Dahlgren (2012) argues, to foster their sense of impact on political life.

[Table 8 here]

Table 8. Informal Civic Participation in Formal Online Spaces: Descriptive Statistics ( $N$ $=1,332)$

In comparison to the results presented in Table 7, those in Table 8 show lower levels of informal participation in formal online spaces than in informal ones, with blogs (Table 7) attracting more students than newspapers. This may be because the formality of newspapers makes them seem less accessible than blogs. It may also be related to the students' habits and views concerning newspaper reading — do they perceive them as being only for adults? The data drawn on in the present study do not shed light on this question.

[Table 9 here]

Table 9. Formal Civic Participation in Traditional and Formal Online Spaces: Descriptive Statistics $(N=1,332)$

It is also clear from Table 9 that young people do not widely appreciate the formal channels for online civic participation made available to all Portuguese citizens. Although they are online, few students use them to participate.

The figures in Tables 7-9 support the view that young people express personal autonomy and agency in social and political spheres if the context provides for it in an accessible form. This is done by sharing and liking videos, images, and other media objects with some political dimension, rather than in formal institutional contexts. Because the Internet — by its nature — creates a space where young people can readily reproduce and distribute content of interest to them and their peers, they are acting as opinion-makers and reinforcing messages. 
The same tables also show that the students see some actions as adult tasks.

These data may reflect the students' sense of not having the capability to act in these contexts, which may be related to their citizenship status being put on hold, as discussed above.

It is worth noting that the messages conveyed within these media objects can be negative for democracy; the contents of the items through which the students engaged were not studied.

\section{Correlations Between Offline and Online Civic Participation and Agency}

Table 10 presents findings on correlations between the composite total scores, characterizing the relationships between offline and online civic participation.

[Table 10 here]

Table 10. Total Score Correlations and Descriptive Statistics $(N=1,194)$

Interestingly, while formal participation offline is positively (albeit weakly) correlated to informal participation online, it is not correlated to the more formal channels of online participation. This supports the suggestions of authors such as Caron (2018), Dahlgren (2012), and Milošević-Đorđević and Žeželj (2017), who argue that there is a need for a closer examination of different forms of online participation, not only traditional forms of formal participation (e.g., voting in formal procedures, public consultations, etc.). The same findings also suggest that online participation also attracts those who are not already engaged offline, reinforcing Sannino's (2008) argument about the relationships between activities and objects, that is, the importance of how objects can create the possibility of transformation.

These results contrast with the findings of Norris (2011) and Prout (2000) suggesting that it is Internet users who were already engaged offline who use the 
Internet for civic purposes. There are several possible reasons for these differences: the different tools and apps available at the time of the different studies, the changing prevalence of Internet and smartphone use, differences between countries, and the age of different study populations.

Furthermore, the more informally engaged students are online, the more they use formal offline and online channels for civic participation - the strongest correlation found, by far. This suggests that effective informal civic action plays a role in leading young people to participate both offline and online through formal channels, making the Internet — the global playground — a living classroom, where they interact with others, learning and reproducing models of citizenship and democracy.

Finally, young people's sense of having opportunities (and thus the ability) to participate is correlated with their effective formal civic action online. This supports Sannino's (2008) ideas on the importance of the object in enabling and shaping transformative agency. It also supports the argument of Ahuja et al. (2018) that technologies provide affordances as mediators of agency and collective action.

\section{Limitations of the Study}

This study is subject to some limitations. For example, it does not explore in depth the reasons why students are not interested in participating in community groups and associations or why they understand some civic actions, both offline and online, to be specific to adults. In order to help us to better understand the transformative processes of young people's development as citizens, future studies could examine whether and under what conditions students recognize their online engagement with content on environment, ethical or gender discrimination as forms of civic participation. Focus group interviews could shed light on this question. 
The study also does not include data on the particular content that the students share, react to, or comment on. It would have been relevant to understand to what extent young people disseminate content that is discriminatory (e.g., racist, xenophobic, etc.) and/or that actively contributes to the propagation of nondemocratic values. Such data would be valuable for studies on the Internet and civic agency. Furthermore, asking students why they share, react to, and comment on civic content could help us better comprehend their levels of civic agency, including the extent to which they trust and feel affection for democracy, and the extent to which these actions are reflective.

A related consideration is that, as the dominant online systems for sharing and interacting with politically and civically engaged content are subject to the commercial agendas of the owners of social media platforms and their clients (Zuboff, 2019), understanding young people's awareness of these potential sources of influence on their online civic actions is of great interest.

Finally, the study only reports on the Portuguese context. However, with its focus on mainstream use of online social networking and traditional ways of offline civic participation, it is likely to reflect patterns in countries with similar democratic systems; further studies should be conducted in other countries.

\section{Conclusions}

This paper looks at the possible interconnections between different facets of young people's civic agency offline and online, formal and informal. I argue that young people's relationship to formal channels of civic participation is likely connected to their experience of their status as citizens kept on hold and that they may prefer to engage with political and civic issues through the informal global playground of the social Internet. 
The findings show that the respondents generally do not participate offline in formal community groups and associations on the environment, human rights, and politics. The most common reason they cite for this is that they simply are not interested in doing so. This lack of interest in offline participation contrasts with the high percentage who report informal forms of online civic participation through content related to the environment, ethnic discrimination, and gender discrimination. These differences between offline and online civic participation suggest that youth tend to use their voice in relationship to public questions on the global playground, by sharing and liking videos, images, and other media objects with some political dimension, rather than in offline formal contexts. The data presented here show both that they have a sense of having the capability to act and that many do effectively engage in such action.

Thus, these results suggest that the Internet is, in fact, a space of youth agency and civic participation — a global playground — contrasting with the world of formal institutions, where youth lack a voice.

To explain their reports of being unable to participate or uninterested in participating in formal offline processes, students mainly cite factors reflecting a lack of agency: e.g., the view that such participation is the responsibility of adults, politicians, or leaders; the voting age; or feelings of powerlessness. These reasons indicate that the students do not perceive themselves to be included in most of these processes (e.g., designing class cohorts, making decisions on the use of school spaces, or participating in national or EU social and/or political issues).

The contrast between the higher percentage of informal online civic participation and the lower percentage of formal online civic participation-effective action —indicates that, as hypothesized, students engage informally with political and social issues via informal online channels than via formal channels either offline or 
online. In choosing to do so, they are manifesting their capacity to participate as agents in these informal spaces and informal cultures. This chosen engagement suggests that less formal and hierarchical structures attract them and foster their civic participation. More importantly, the correlations show that the more civically engaged they are online in an informal fashion, the more the students engage with formal channels for civic participation as well.

Moreover, these findings can contribute to the wider discussion about the role of the informal civic affordances of online tools and platforms in the development of youth-led movements. One example is the worldwide growth of the School strike for the climate movement, led by students across many countries, whose most recognized leader has been the Swedish high school student Greta Thunberg. While the affordance for globalized conversation among young people can be seen with, for example, multiple player online games, this movement of internationally organized strikes has shown that the Internet offers young people means of self-mobilization, selforganization, self-realization, and autonomy around civic issues. Increased informal online civic engagement may be one of the factors contributing to their entry into formal civic action, transposing online engagements into offline action, and transforming the discussion and the political agenda on climate change. The informal online affordances used by young people in this movement contrast with the hierarchical spaces and adult voices of traditional democratic institutional structures.

Thus, for young people the global playground that is the Internet may represent a space of transformative civic agency (Caron, 2018; Dahlgren, 2012; Sannino, 2008). This implies the need for researchers studying youth civic agency to look not only at new technological forms of civic participation, but also to be aware of social structure that influences our uses of technologies (and vice versa). Time and further research, 
however, are required to understand to what extent these informal and less structured online actions may be contributing to transformations of traditional democratic culture, from a status quo that treats young people as citizens on hold, to a new situation where they are treated as full citizens. Further studies may also help us to understand whether and to what extent these actions may be shaping and transforming political structures that prevent young people from fully participating in political decision-making.

This study also raises important questions on the balance between protecting young people online and providing them with a sense of empowerment to act purposively and reflectively as civic agents. Over the years, Western societies have decided to adopt public policies on young people's health and education, teaching them about social issues such as drugs, sexually transmitted infections, bullying, racism, and domestic violence. The intention has been to allow children to access information, acquire knowledge, develop skills, and make informed and autonomous decisions, both in school and among peers on the playground. The same premise should apply in the digital sphere. However, this should not mean replicating formal, hierarchical, skillintensive offline practices online, preventing young people from having access to informal spaces of civic participation.

While it is necessary to regulate online service providers to prevent abuse and misuse of personal data, children and young people must also be equipped with digital and media skills that enable them to be less vulnerable, more critical, and more capable of interacting with social and political issues online in a positive and constructive manner. In addition, schools have a determining role in promoting media literacy, which can allow students to make sense of the discourse, values, and messages conveyed through media, recognizing that all media texts are constructed, made to attract attention, and have one or more purposes, such as monetary gain or spreading a political 
ideal. This can allow students to be autonomous and increase their capability, as civic agents, to change and remake the world they live in.

\section{Acknowledgments}

Thanks to Paul Reeve for proofreading.

\section{References}

Ahuja, M., Patel, P., \& Suh, A. (2018, January). The influence of social media on collective action in the context of digital activism: An affordance approach.Proceedings of the 51st Hawaii International Conference on System Sciences 2018 (pp. 2203-2212). Red Hook, NY: Curran Associates, Inc. doi:10.24251/HICSS.2018.275

Lei no. 8/2009—Regime jurídico dos Conselhos Municipais de Juventude [Legal regime for municipal youth councils] (2009).

Banaji, S., \& Buckingham, D. (2010). Young people, the Internet, and civic participation: An overview of key findings from the CivicWeb project. International Journal of Learning and Media, 2(1), 15-24.

Banaji, S., \& Buckingham, D. (2013). The civic web. Cambridge, MA: MIT Press.

Bennett, W. (2008). Changing citizenship in the digital age. In W. L. Bennett (Ed.), Civic life online: Learning how digital media can engage youth (pp. 1-24). Cambridge, MA: MIT Press.

Bennett, W., \& Segerberg, A. (2012). The logic of connective action. Information, Communication \& Society, 15(5), 739-768.

https://doi.org/10.1080/1369118X.2012.670661

Boerl, W. (2013). From monologue to dialogue: How the Internet is empowering the evangelical periphery. Information, Communication \& Society, 16(8), 1223-1241.

Bourdieu, P. (1986). The forms of capital. In J. G. Richardson (Ed.), Handbook of theory and research for sociology of education (pp. 241-258). Westport, CT:

Greenwood.

Bragg, S. (2007). Consulting young people: A literature review (2nd ed.). Newcastle, England: Creativity, Culture and Education.

Cammaerts, B. (2008). Critiques on the participatory potentials of Web 2.0. Communication, Culture \& Critique, 1(4), 358-377. https://doi.org/10.1111/j.17539137.2008.00028.x

Caron, C. (2018). Speaking up about bullying on YouTube: Teenagers' vlogs as civic engagement. Canadian Journal of Communication, 42(4), 645-668.

http://doi.org/10.22230/cjc.2017v42n4a3156 
Clot, Y. (2009). Clinic of activity: The dialogue as an instrument. In A. Sannino, H. Daniels, \& K. Gutiérrez (Eds.), Learning and expanding with activity theory (pp. 286303). Cambridge, England: Cambridge University Press.

Coleman, S. (2006). Digital voices and analogue citizenship: Bridging the gap between young people and the democratic process. Public Policy Research, 13(4), 257-261. https://doi.org/10.1111/j.1070-3535.2006.00451.x

Dahlgren, P. (2006). Civic identity and net activism: The frame of radical democracy. In L. Dahlberg \& E. Siapera (Eds.), Radical democracy and the Internet (pp. 55-72). London, England: Palgrave MacMillan.

Dahlgren, P. (2012). Reinventing participation: Civic agency and the web environment. Geopolitics, History, and International Relations, 4(2), 27-45.

Davies, J. A., \& Merchant, G. (2009). Web 2.0 for schools: Learning and social participation. New York, NY: Peter Lang.

Dias Fonseca, T. (2015). e-Literacy, schools and municipalities towards a common goal: e-Citizenship (Doctoral dissertation).University of Lisbon, Portugal, New University of Lisbon, Portugal and University of Aveiro, PortugalRetrieved from http://hdl.handle.net/10451/19925

Dias Fonseca, T., \& Potter, J. (2016). Media education as a strategy for online civic participation in Portuguese schools. Comunicar: Media Education Research Journal, 24(49), 9-17. https://doi.org/10.3916/C49-2016-01

Feezell, J. T., Conroy, M., \& Guerrero, M. (2009, September). Facebook is... fostering political engagement: A study of online social networking groups and offline participation. Paper presented at APSA 2009, Toronto, Canada.

Forestiere, C. (2015). Promoting civic agency through civic-engagement activities: A guide for instructors new to civic-engagement pedagogy. Journal of Political Science Education, 11, 455-471. https://doi.org/10.1080/15512169.2015.1066684

Giddens, A. (1984). The constitution of society: Outline of the theory of structuration. Cambridge, England: Polity.

Greenfield, A. (2017). Radical technologies: The design of everyday life. London, England: Verso.

Hart, R. (1992). Children's participation: From tokenism to citizenship (Innocenti Essay No. 4). Florence, Italy: International Child Development Centre. Retrieved from UNICEF website: https://goo.gl/a9XmdL

Hasebrink, U., Livingstone, S., Haddon, L., \& Ólafsson, K. (2009). Comparing children's online opportunities and risks across Europe: Cross-national comparisons for EU Kids Online (Deliverable D3.2, 2nd ed.). London, England: EU Kids Online. Retrieved from http://goo.gl/lkbDvw 
Hays, S. (1994). Structure and agency and the sticky problem of culture. Sociological Theory, 12(1), 57-72. https://doi.org/10.2307/202035

Head, B. (2011). Why not ask them? Mapping and promoting youth participation. Children and Youth Services Review, 33(4), 541-547.

http://dx.doi.org/10.1016/j.childyouth.2010.05.015

Hirst, P. (2013). From statism to pluralism: Democracy, civil society and global politics. New York, NY: Routledge.

Inden, R. (2000). Imagining India (2nd ed.). London, England: C. Hurst \& Co.

Jackson D., Alexander, J., Thorsen, E., and Savigny, H. (2015). Introduction. In. H. Savigny, E. Thorsen, D. Jackson, J. Alexander (Eds.), Media, Margins and Civic Agency (pp 1-12). London: Palgrave MacMillan. https://doi.org/ $10.1057 / 9781137512642$

Jans, M. (2004). Children as citizens: Towards a contemporary notion of child participation. Childhood, 11(1), 27-44. https://doi.org/10.1177/0907568204040182

Jenkins, H. (2006). Convergence culture: Where old and new media collide. New York, NY: New York University Press.

Jenkins, H., Clinton, K., Purushotma, R., Robinson, A. J., \& Weigel, M. (2006). Confronting the challenges of participatory culture: Media education for the 21st century. Cambridge, MA: MIT Press.

Jenkins, H., Shresthova, S., Gamber-Thompson, L., Kligler-Vilenchik, N., \& Zimmerman, A. (2016). By any media necessary: The new youth activism. New York, NY: NYU Press.

Johnson, B. R., Onwuegbuzie, A. J., \& Turner, L. A. (2007). Toward a definition of mixed methods research. Journal of Mixed Methods Research, 1(2), 112133. https://doi.org/10.1177/1558689806298224

Kahne, J., Middaugh, E., \& Allen, D. (2015). Youth, new media, and the rise of participatory politics. In D. Allen \& J. S. Light (Eds.), From voice to influence: Understanding citizenship in a digital age (pp. 35-59). Chicago, IL: University of Chicago Press.

Kirby, P., Lanyon, C., Cronin, K., \& Sinclair, R. (2003). Building a culture of participation involving children and young people in policy, service planning, delivery and evaluation. London, England: Department for Education and Skills.

Klingemann, H. (2013). Dissatisfied democrats: Evidence from old and new democracies. In R. J. Dalton \& C. Welzel (Eds.), The civic culture revisited: From allegiant to assertive citizens (pp. 116-157). Cambridge, England: Cambridge University Press. 
Livingstone, S., \& Third, A. (2017). Children and young people's rights in the digital age: An emerging agenda. New Media \& Society, 19(5), 657-670.

https://doi.org/10.1177/1461444816686318

Lucero, J., Wallerstein, N., Duran, B., Alegria, M., Greene-Moton, E., Israel, B., \& White Hat, E. R. (2018). Development of a mixed methods investigation of process and outcomes of community-based participatory research. Journal of Mixed Methods Research, 12(1), 55-74. https://doi.org/10.1177/1558689816633309

Macintosh, A. (2004, January). Characterizing e-participation in policy-making. In R. Sprague (Ed.), Proceedings of the 37th Annual Hawaii International Conference on System Sciences. Waikoloa, HI. https://doi.org/10.1109/HICSS.2004.1265300

Macintosh, A., \& Whyte, A. (2006, September). Evaluating how eParticipation changes local democracy. Paper presented at the eGovernment Workshop '06, London, England.

Magalhães, P. (2005). Disaffected democrats: Political attitudes and political action in Portugal. West European Politics, 28(5), 973-991.

https://doi.org/10.1080/01402380500310626

Milošević-Đorđević, J. S., \& Žeželj, I. L. (2017). Civic activism online: Making young people dormant or more active in real life? Computers in Human Behavior, 70, 113118. https://doi.org/10.1016/j.chb.2016.12.070

Norris, P. (2011). Democratic deficit: Critical citizens revisited. Cambridge, England: Cambridge University Press.

OECD. (2003). The e-government imperative: Main findings (Policy brief). Paris, France: OECD Publishing. Retrieved from http://unpan1.un.org/intradoc/groups/public/documents/APCITY/UNPAN015120.pdf

Pearce, K. E., \& Rice, R. E. (2017). Somewhat separate and unequal: Digital divides, social networking sites, and capital-enhancing activities. Social Media + Society, 3(2), 1-16. https://doi.org/10.1177/2056305117716272

Pharr, S. J., \& Putnam, R. (2000). Disaffected democracies: What's troubling the trilateral countries? Princeton, NJ: Princeton University Press.

Possey, D., Shonfeld, M., Appleby, L., Judge, M., Saito, T., \& Smits, A. (2018). Digital agency: Empowering equity in and through education. Technology, Knowledge and Learning, 23, 425-439. https://doi.org/10.1007/s10758-018-9384-x

Prout, A. (2000). Children's participation: Control and self-realisation in British late modernity. Children \& Society, 14(4), 304-315. https://doi.org/10.1111/j.1099$\underline{0860.2000 . t b 00185 . x}$

Puljek-Shank, R. (2018). Civic agency in governance: The role of legitimacy with citizens vs. donors. Voluntas, 29(4) 870-883. https://doi.org/10.1007/s11266-0180020-0 
Putnam, R. D. (1995). Bowling alone: America's declining social capital. Journal of Democracy, 6(1), 65-78. https://doi.org/10.1353/jod.1995.0002

Sannino, A. (2008). From talk to action: Experiencing interlocution in developmental interventions. Mind, Culture, and Activity, 15(3), 234-257.

https://doi.org/10.1080/10749030802186769

Sasaki, F. (2016). Online political efficacy (OPE) as a reliable survey measure of political empowerment when using the Internet. Policy \& Internet, 8(2), 197-214. https://doi.org/10.1002/poi3.114

Shah, D. V. (1998). Civic engagement, interpersonal trust, and television use: An individual-level assessment of social capital. Political Psychology, 19(3), 469-496. https://doi.org/10.1111/0162-895X.00114

Shier, H. (2001). Pathways to participation: Openings, opportunities and obligations. Children \& Society, 15(2), 107-117. https://doi.org/10.1002/CHI.617Sormanen, N., \& Dutton, W. (2015). The role of social media in societal change: Cases in Finland of fifth estate activity on Facebook. Social Media + Society, 1(2). https://doi.org/10.1177/2056305115612782

Tarrow, S. (2014). Response to W. Lance Bennett's review of The Language of Contention: Revolutions in Words. Perspectives on Politics, 12(2), 472-473. https://doi.org/10.1017/S1537592714001029

Torcal, M. (2006). Political disaffection and democratization history in new democracies. In M. Torcal \& J. R. Montero (Eds.), Political disaffection in contemporary democracies: Social capital, institutions and politics (pp. 157-189). London, England: Routledge.

Vissers, S., \& Stolle, D. (2014). The Internet and new modes of political participation: Online versus offline participation. Information, Communication \& Society, 17(8), 937955. https://doi.org/10.1080/1369118X.2013.867356

Wells, C. (2015). The civic organization and the digital citizen: Communicating engagement in a networked age. New York, NY: Oxford University Press.

Zuboff, S. (2019). The age of surveillance capitalism: The fight for a human future at the new frontier of power. London, England: Profile Books. 


\section{Funding details}

This work was supported by the Portuguese Foundation for Science and Technology under Grant SFRH/BD/78276/2011

\section{Disclosure statement}

The author declares no conflict of interest. 
Table 1

Example questionnaire items analysed

\begin{tabular}{|c|c|c|}
\hline $\begin{array}{l}\text { Off- and Online forms of } \\
\text { civic participation }\end{array}$ & $\begin{array}{l}\text { Example questionnaire } \\
\text { items analysed }\end{array}$ & $\begin{array}{l}\text { Traditional or non- } \\
\text { traditional form of civic } \\
\text { participation }\end{array}$ \\
\hline $\begin{array}{l}\text { Formal forms of offline civic } \\
\text { participation }\end{array}$ & $\begin{array}{l}\text { Environment } \\
\text { Volunteering } \\
\text { Human Rights } \\
\text { Student union }\end{array}$ & Traditional \\
\hline $\begin{array}{l}\text { Informal forms of civic } \\
\text { participation via online social } \\
\text { networks }\end{array}$ & $\begin{array}{l}\text { Like videos about the } \\
\text { environment } \\
\text { Commented on images } \\
\text { about gender } \\
\text { discrimination }\end{array}$ & Non-traditional \\
\hline $\begin{array}{l}\text { Informal civic participation in } \\
\text { formal online spaces }\end{array}$ & $\begin{array}{l}\text { Commented on } \\
\text { newspaper webpages } \\
\text { Voted in newspaper } \\
\text { polls online }\end{array}$ & Non-traditional \\
\hline $\begin{array}{l}\text { Formal civic participation in } \\
\text { traditional and online spaces }\end{array}$ & $\begin{array}{l}\text { Signed a petition } \\
\text { online } \\
\text { Took part in a protest } \\
\text { or campaign online }\end{array}$ & Traditional \\
\hline
\end{tabular}


Table 2

Composite score characterizations

\begin{tabular}{|c|c|c|c|}
\hline $\begin{array}{l}\text { Composite } \\
\text { Score name }\end{array}$ & $\begin{array}{l}\text { Composite } \\
\text { content }\end{array}$ & $\begin{array}{l}\text { Example } \\
\text { questionnaire items }\end{array}$ & Scoring process \\
\hline $\begin{array}{l}\text { Offline civic } \\
\text { participation }\end{array}$ & $\begin{array}{l}\text { Formal offline } \\
\text { civic } \\
\text { participation }\end{array}$ & $\begin{array}{l}\text { Have you voted in } \\
\text { student union } \\
\text { elections? } \\
\text { Have you participated } \\
\text { in groups related to: } \\
\text { the environment; } \\
\text { human rights; scouts; } \\
\text { the arts; politics? } \\
\text { Have you } \\
\text { volunteered? }\end{array}$ & $\begin{array}{l}\text { Voting: } 1 \mathrm{pt} \\
\text { Sports: } 1 \mathrm{pt} \\
\text { Other collectives }^{2}: 2 \\
\text { points } \mathrm{Max}=5 \text { points }\end{array}$ \\
\hline $\begin{array}{l}\text { Informal online } \\
\text { civic } \\
\text { participation }\end{array}$ & $\begin{array}{l}\text { Online } \\
\text { informal civic } \\
\text { actions in } \\
\text { online social } \\
\text { networks or } \\
\text { newspapers }\end{array}$ & $\begin{array}{l}\text { Have you: shared } \\
\text { links, videos or } \\
\text { images related to the } \\
\text { environment; "Liked" } \\
\text { images, videos, or } \\
\text { comments on gender } \\
\text { discrimination? }\end{array}$ & $\begin{array}{l}\text { Consulting: } 1 \mathrm{pt} \\
\text { Start/Participate: } 2 \text { pts } \\
\text { Voting: } 2 \text { pts } \\
\text { Max }=7 \text { points }\end{array}$ \\
\hline
\end{tabular}

${ }^{2}$ If they gave at least two "yes" answers, the 2 points would be given. 


\begin{tabular}{llll}
\hline Formal online & Online civic & Have you: Started a & Consulting: 1 pt \\
civic & participation & protest or campaign; & Start/Participate: $2 \mathrm{pts}$ \\
participation & using formal & Signed a petition; & Voting: $2 \mathrm{pts}$ \\
& channels & Participated in & Max=7 points \\
& & decision-making & \\
& & processes & \\
\hline Perceived & Perceptions of & Students'association; & Yes, I can: $1 \mathrm{pt}$ \\
opportunities & what they can & National student life; & Yes, but I'm not \\
to participate & participate in & National social issues; & interested: $1 \mathrm{pt}$ \\
& & National/European & No, I can't: $0 \mathrm{pts}$ \\
& & political issues & Max= 11 points \\
& & &
\end{tabular}


Table 3

Students' offline civic participation in formal community groups: Descriptive statistics $(N=1,332)$

No Yes $\quad$ Missing

$(\%)$

$(\%)$

$(\%)$

\begin{tabular}{lccc}
\hline Environment & 73.6 & 19.1 & 7.4 \\
Human Rights & 83.8 & 8.1 & 8.2 \\
Sports Team & 28.6 & 66.9 & 4.5 \\
Scouts & 72.3 & 20.8 & 6.9 \\
Cultural & 57.9 & 35.2 & 6.9 \\
Political & 81.6 & 10.6 & 7.8 \\
Volunteering & 57.7 & 35 & 7.3 \\
\hline
\end{tabular}


Table 4

To what extent do you think you can participate: descriptive statistics $(N=1,332)$

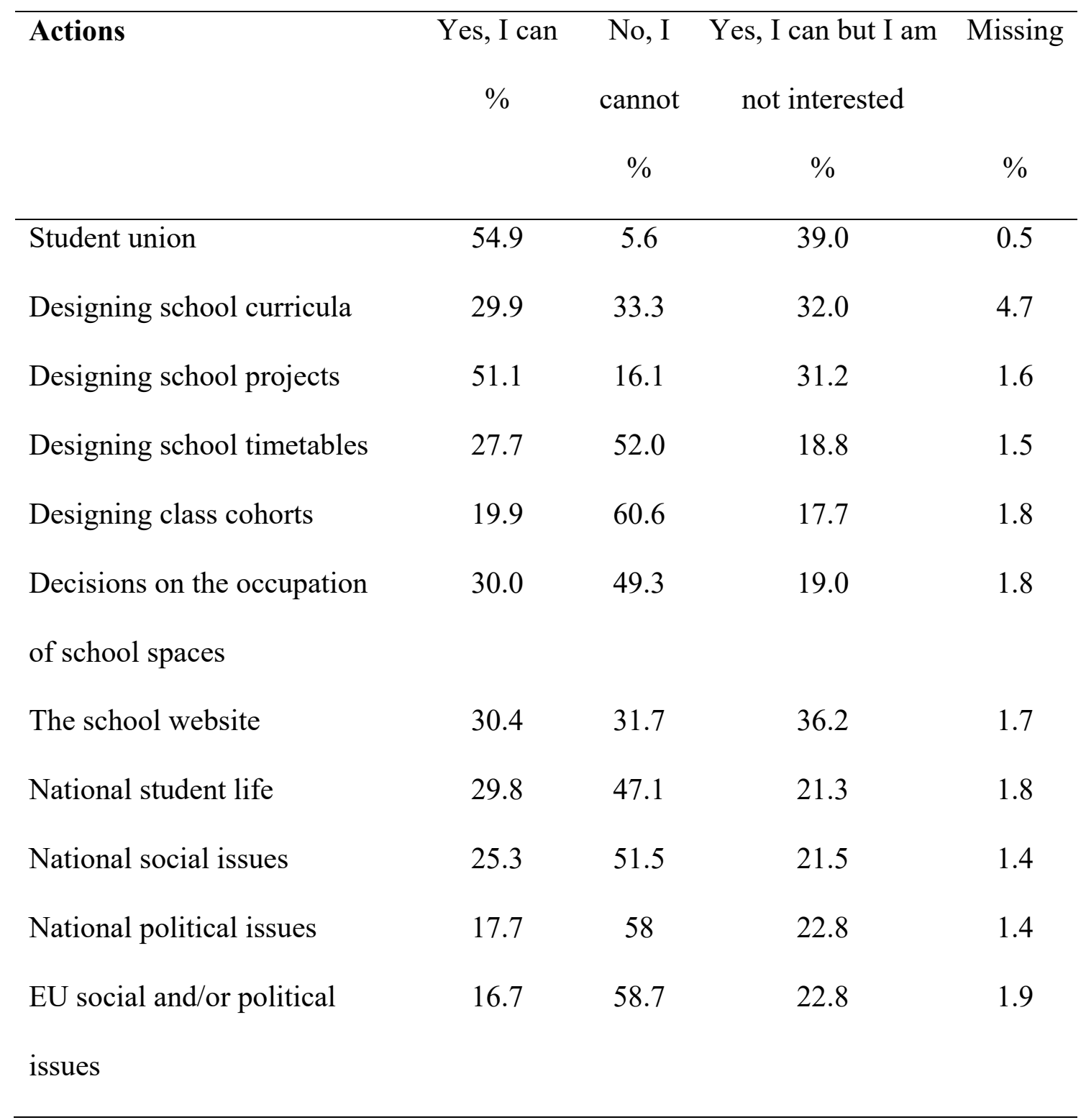


Table 5

Students' reasons for not participating or declining to participate formally offline:

Descriptive statistics ( $\mathrm{n}=779$ and $\mathrm{n}=775$, respectively)

\section{I can't participate}

$\%$

\begin{tabular}{cccccc}
\hline Responsibility & Must be & Not & Feeling of & Nothin & No time due \\
of & over 18 & interested in & powerlessnes & g to & to school \\
adults/politicians & & politics & $\mathrm{s}$ & change & demands \\
10.2 & 10.2 & 12.9 & 21.2 & 23.5 & 1.4 \\
& & & & & \\
\hline
\end{tabular}

I can, but I'm not interested

$\%$

\begin{tabular}{lllll}
\hline Lack of & Responsibility & Must be over & Disbelief in & Nothing to \\
empowerment & of & 18 & politicians/ & change \\
& adults/leaders & & political & \\
& & & system & 3.1 \\
\hline
\end{tabular}


Table 6

Access to the internet per device: descriptive statistics $(N=1,332)$

Frequency

Smartphone

Home computer

$\%$

$\%$

Once a month

10.3

2.0

Once a week

10.3

8.6

Once a day

14.7

25.8

Several times a day

53.8

61.7

I don't have that device

9.7

1.6

Missing values

1.2

0.3 
Table 7

Informal forms of civic participation via online social networks: descriptive statistics $(N=1,332)$

\begin{tabular}{|c|c|c|c|c|}
\hline \multicolumn{2}{|c|}{ Forms of engagement } & $\begin{array}{c}\text { They do } \\
\%\end{array}$ & $\begin{array}{l}\text { They think } \\
\text { only } \\
\text { teachers } \\
\text { do } \\
\% \\
\end{array}$ & $\begin{array}{c}\text { Missing } \\
\text { values } \\
\%\end{array}$ \\
\hline \multirow{4}{*}{$\begin{array}{l}\text { Like } \\
\text { images/videos/ } \\
\text { comments about }\end{array}$} & environment & 59.8 & 29.1 & 11.1 \\
\hline & ethnic discrimination & 56.4 & 25.5 & 18.1 \\
\hline & gender discrimination & 53 & 25.9 & 21.1 \\
\hline & $\begin{array}{c}\text { social, political or } \\
\text { economic issues }\end{array}$ & 40.9 & 49.0 & 10.1 \\
\hline \multirow{4}{*}{$\begin{array}{l}\text { Commented on } \\
\text { images/videos/ } \\
\text { posts about }\end{array}$} & the environment & 23.7 & 48.3 & 28 \\
\hline & ethnic discrimination & 24 & 45.3 & 30.7 \\
\hline & gender discrimination & 23 & 44.9 & 32.2 \\
\hline & $\begin{array}{c}\text { social, political or } \\
\text { economic issues }\end{array}$ & 20.3 & 58.3 & 21.4 \\
\hline \multirow{4}{*}{$\begin{array}{l}\text { Shared } \\
\text { images/videos/ } \\
\text { comments } \\
\text { about }\end{array}$} & the environment & 29.7 & 46.9 & 23.3 \\
\hline & ethnic discrimination & 28.5 & 43.8 & 27.7 \\
\hline & gender discrimination & 71.1 & 6.4 & 1.6 \\
\hline & $\begin{array}{c}\text { social, political or } \\
\text { economic issues }\end{array}$ & 21.7 & 59.5 & 18.8 \\
\hline Shared links & online petitions & 26.5 & 42.7 & 30.8 \\
\hline \multirow{2}{*}{$\begin{array}{l}\text { Shared links, } \\
\text { videos or images } \\
\text { from groups or } \\
\text { demonstrations } \\
\text { from: }\end{array}$} & their country & 26.7 & 55.4 & 17.9 \\
\hline & other countries & 22.1 & 52.2 & 25.8 \\
\hline $\begin{array}{l}\text { Commented on } \\
\text { blogs from: }\end{array}$ & their country & 28.6 & 38.7 & 32.7 \\
\hline $\begin{array}{l}\text { Voted in polls on } \\
\text { blogs from: }\end{array}$ & their country & 17.3 & 33.9 & 42.6 \\
\hline
\end{tabular}

Table 8

Informal civic participation in formal online spaces: descriptive statistics $(N=1,332)$

\begin{tabular}{lccc}
\hline Forms of engagement & $\begin{array}{c}\text { They do } \\
\%\end{array}$ & $\begin{array}{c}\text { They think only } \\
\text { Teachers do } \\
\%\end{array}$ & $\begin{array}{c}\text { Missing } \\
\text { values } \\
\%\end{array}$ \\
\hline $\begin{array}{l}\text { Commented on newspaper } \\
\text { webpages }\end{array}$ & 16.2 & 54.6 & 29.2 \\
Voted in newspaper polls online & 13.5 & 43.8 & 42.6 \\
\hline
\end{tabular}


Table 9

Formal civic participation in traditional and formal online spaces: descriptive statistics $(N=1,332)$

\begin{tabular}{|c|c|c|c|}
\hline Forms of engagement & $\begin{array}{l}\text { They do } \\
\%\end{array}$ & $\begin{array}{c}\text { They think } \\
\text { only Teachers } \\
\text { do } \\
\%\end{array}$ & $\begin{array}{l}\text { Missin } \\
\mathrm{g} \\
\text { values } \\
\% \\
\end{array}$ \\
\hline Signed a petition online & 27.7 & 41.5 & 30.9 \\
\hline Took part in a protest or campaign online & 19.4 & 54.7 & 25.9 \\
\hline Started a protest or campaign online & 6.5 & 42.5 & 51.1 \\
\hline $\begin{array}{l}\text { Started a Portuguese government } \text { My movement }^{3} \\
\text { Online }\end{array}$ & 2.8 & 32.6 & 64.6 \\
\hline $\begin{array}{l}\text { Voted on a Portuguese government "My } \\
\text { movement" online }\end{array}$ & 3.3 & 43.8 & 52.9 \\
\hline $\begin{array}{l}\text { Consulted municipal documents from a public } \\
\text { decision-making process }\end{array}$ & 13.9 & 55.5 & 30.6 \\
\hline $\begin{array}{l}\text { Participated in a formal governmental public } \\
\text { decision-making process }\end{array}$ & 5.4 & 59 & 35.6 \\
\hline $\begin{array}{l}\text { Participated in formal municipal online discussion } \\
\text { forums }\end{array}$ & 5.1 & 52.3 & 42.6 \\
\hline $\begin{array}{l}\text { Presented suggestions or reported problems to the } \\
\text { local authorities via online services or email }\end{array}$ & 4.6 & 51.9 & 43.5 \\
\hline
\end{tabular}

${ }^{3}$ My movement (translated from Portuguese: Meu Movimento) was an initiative of the

Portuguese government to hear and support citizens' ideas and suggestions. It was online and available to any Portuguese citizen. After proposing an idea or a movement, the most voted online would be able to discuss it with the Prime Minister. 
Table 10

Total score correlations and descriptive statistics $(N=1,194)$

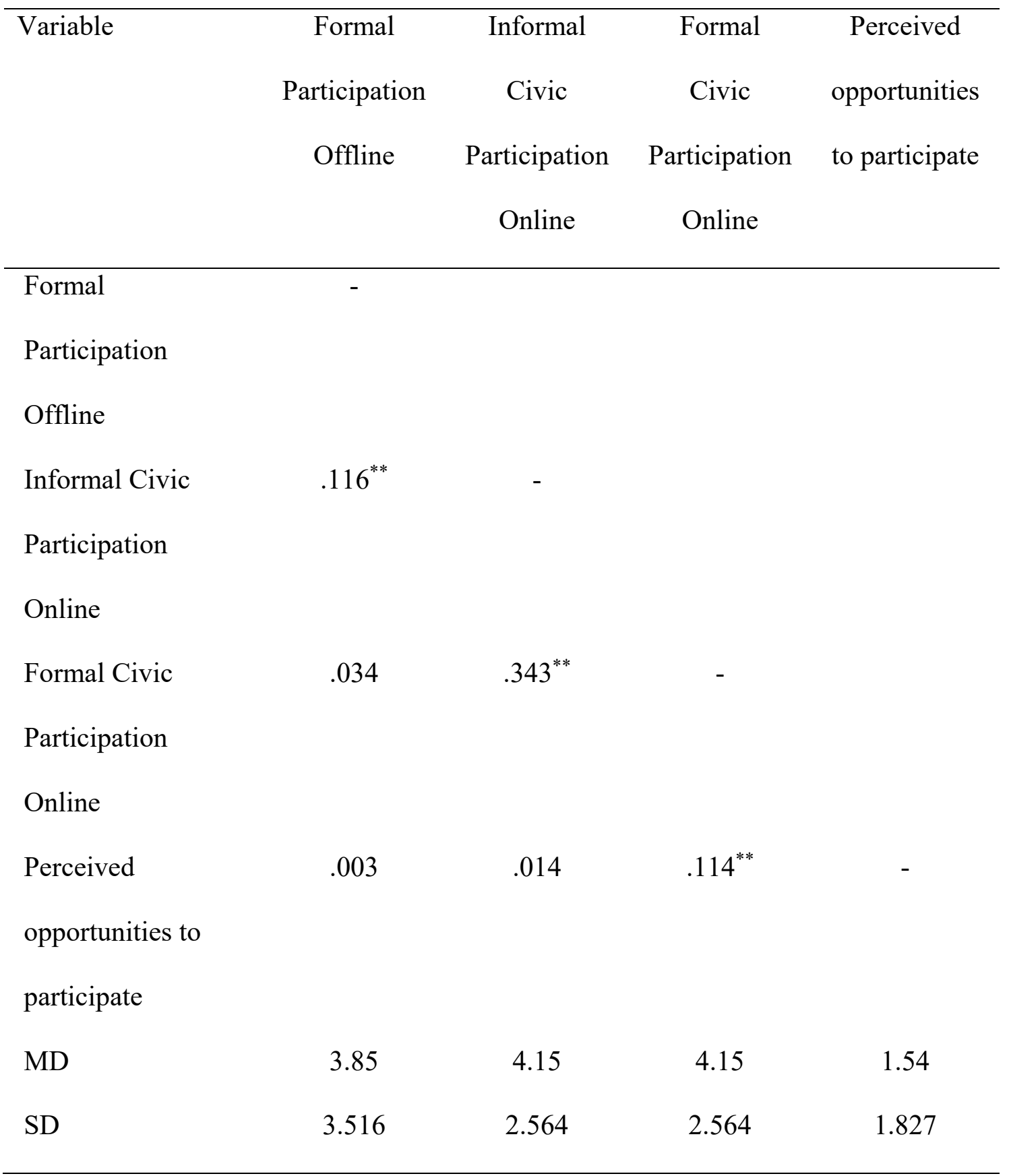

$* \mathrm{p}<.05 . * * \mathrm{p}<.01$ 